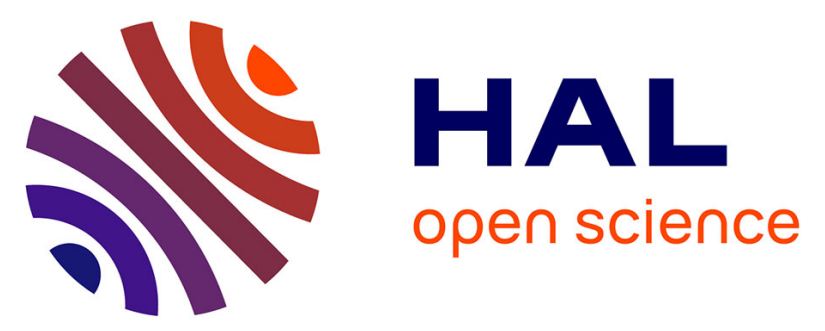

\title{
Water soluble dicarboxylic acids and related compounds in Antarctic aerosols
}

\author{
Kimitaka Kawamura, Richard Sempere, Yoshie Imai, Yoshiyuki Fujii, \\ Masahiko Hayashi
}

\section{- To cite this version:}

Kimitaka Kawamura, Richard Sempere, Yoshie Imai, Yoshiyuki Fujii, Masahiko Hayashi. Water soluble dicarboxylic acids and related compounds in Antarctic aerosols. Journal of Geophysical Research: Atmospheres, 1996, 101 (D13), pp.18721-18728. 10.1029/96JD01541 . hal-02053057

\section{HAL Id: hal-02053057 https://hal-amu.archives-ouvertes.fr/hal-02053057}

Submitted on 6 Feb 2021

HAL is a multi-disciplinary open access archive for the deposit and dissemination of scientific research documents, whether they are published or not. The documents may come from teaching and research institutions in France or abroad, or from public or private research centers.
L'archive ouverte pluridisciplinaire HAL, est destinée au dépôt et à la diffusion de documents scientifiques de niveau recherche, publiés ou non, émanant des établissements d'enseignement et de recherche français ou étrangers, des laboratoires publics ou privés. 


\title{
Water soluble dicarboxylic acids and related compounds in Antarctic aerosols
}

\author{
Kimitaka Kawamura, ${ }^{1}$ Richard Seméré, ${ }^{2}$ and Yoshie Imai ${ }^{1}$ \\ Department of Chemistry, Faculty of Science, Tokyo Metropolitan University, Tokyo, Japan \\ Yoshiyuki Fujii \\ National Institute of Polar Research, Tokyo, Japan \\ Masahiko Hayashi \\ Solar Terrestrial Environment Laboratory, Nagoya University, Nagoya, Japan
}

\begin{abstract}
Antarctic aerosols collected at Syowa Station were studied for water soluble organic compounds by employing a water extraction and dibutyl ester derivatization and using a capillary gas chromatography (GC) and GC/mass spectrometry ( $\mathrm{GC} / \mathrm{MS})$. Total carbon and nitrogen were also determined. A homologous series of $\alpha, \omega$-dicarboxylic acids $\left(\mathrm{C}_{2}-\mathrm{C}_{11}\right)$, $\omega$-oxocarboxylic acids $\left(\mathrm{C}_{2}-\mathrm{C}_{9}\right)$, and $\alpha$ dicarbonyls $\left(\mathrm{C}_{2}-\mathrm{C}_{3}\right)$ were detected, as well as pyruvic acid and aromatic (phthalic) diacid. Succinic $\left(\mathrm{C}_{4}\right)$ or oxalic $\left(\mathrm{C}_{2}\right)$ acid was found to be the dominant diacid species, followed by azelaic $\left(\mathrm{C}_{9}\right)$, adipic $\left(\mathrm{C}_{6}\right)$, or malonic $\left(\mathrm{C}_{3}\right)$ acid. Concentration range of the total diacids was $5.9-88 \mathrm{ng} \mathrm{m}^{-3}$, with an average of $29 \mathrm{ng} \mathrm{m}^{-3}$. Highest concentrations were observed in the summer sample with a predominance of succinic acid $\left(61.5 \mathrm{ng} \mathrm{m}^{-3}\right)$, which comprised approximately $70 \%$ of the total diacids and accounted for $3.5 \%$ of total aerosol carbon $\left(1020 \mathrm{ng} \mathrm{m}^{-3}\right)$. The succinic acid $\left(\mathrm{C}_{4}\right)$ is likely produced by photooxidation of 4-oxocarboxylic acids, which are present in the atmosphere as intermediates of the photooxidation of unsaturated fatty acids. These results indicate that the Antarctic organic aerosols originate from marine-derived lipids and are transformed largely by photochemical oxidations. $\omega$-Oxocarboxylic acids $\left(\mathrm{C}_{2}-\mathrm{C}_{9}, 0.36-3.0 \mathrm{ng} \mathrm{m}^{-3}\right)$ also showed the highest concentration in the summer sample, again suggesting a secondary production in the atmosphere of the Antarctic and in the Southern Ocean.
\end{abstract}

\section{Introduction}

Antarctica is the continent surrounded by the Southern Ocean, in which long-range atmospheric transport of anthropogenic pollutants is insignificant, whereas natural sources such as seawaters are important contributors to the marine aerosols through sea/air interaction. This is in contrast to the Arctic, which is surrounded by the Eurasian and North American continents and is a cold sink for anthropogenic organic and inorganic materials transported long distance through the atmosphere from midlatitudes [Barrie, 1986; Barrie

\footnotetext{
${ }^{1}$ Now at Institute of Low Temperature Science, Hokkaido University, Sapporo Japan.

${ }^{2}$ Now at CNRS, Campus de Luminy, Marseille, France.
}

Copyright 1996 by the American Geophysical Union.

Paper number 96JD01541.

0148-0227/96/96JD-01541\$09.00 and Barrie, 1990]. In analogy, midlatitudinal aerosols in the southern hemisphere may also be transported to the far south and deposited on the Antarctic ice sheet. Thus the chemical species stored in an ice core, from which past atmospheric information can be reconstructed [Delmas, 1992], are largely dependent on the aerosol chemical composition in the Antarctic region. Antarctic aerosols have been studied mostly for inorganic constituents [e.g., Itoh, 1989], and there are very few studies on the organic chemistry.

In a previous study [Nishikiori et al., 1996], we analyzed Antarctic aerosols for the distributions of solvent extractable fatty acids and related lipid compounds. Their molecular distributions showed that the Antarctic aerosols are largely contributed from biological sources; however, labile compounds such as unsaturated fatty acids are depleted, and photochemical reaction products such as nonanoic acid and azelaic acid are abundantly detected. Although this study showed a significant photochemical transformation of the organic aerosols in the Antarctic region, water soluble organic compounds such as small diacids (e.g., oxalic acid) were 
not determined due to the limitation of the methodology used (solvent extraction and methyl ester derivatization).

Oxalic, malonic, and succinic and other dicarboxylic acids are ubiquitous organic aerosol constituents in the urban, marine, and Arctic atmosphere [e.g., Grosjean et al., 1978; Norton et al., 1983; Kawamura and Kaplan, 1987; Li and Winchester, 1993]. In the midlatitudes, their concentrations show a diurnal distribution with a daytime maximum [Satsumabayashi et al., 1990; K. Kawamura and O. Yasui, unpublished results, 1990] and increase in the summer of the year [Kawamura and Ikushima, 1993]. On the contrary, in the Arctic atmosphere, the diacids show a concentration maximum in early April as a result of enhanced photochemical production at a polar sunrise [Kawamura et al., 1995a]. Photochemical oxidations of anthropogenic hydrocarbons and biogenic organic matter are the sources of atmospheric dicarboxylic acids [Grosjean et al., 1978; Hatakeyama et al., 1985, 1987; Yokouchi and Ambe, 1986; Kawamura and Gagosian, 1987; Kawamura and Ikushima, 1993], as well as direct emission from internal combustion engines [Kawamura and Kaplan, 1987]. Thus dicarboxylic acids accumulate in the aerosols and account for up to $1.1 \%$ of the total aerosol carbon in the urban Tokyo atmosphere [Kawamura and Ikushima, 1993], 9.1\% in the Arctic atmosphere (K. Kawamura et al., manuscript in preparation, 1996), and $15 \%$ in the remote Pacific atmosphere (F. Sakaguchi and K. Kawamura, High abundance of oxalic and malonic acids in the remote marine aerosols from equatorial to western North Pacific, submitted to Geophysical Research Letters, 1996 (hereinafter referred to as Sakaguchi and Kawamura, submitted manuscript, 1996)).

In this paper, we studied Antarctic aerosol samples for low molecular weight dicarboxylic acids, ketocarboxylic acids, and $\alpha$-dicarbonyls using gas chromatography and mass spectrometry. The aerosols were also analyzed for total carbon and nitrogen contents. Here we present molecular distributions of these water soluble organic compounds and a large increase of their concentrations during summertime. We also discuss the source of the dicarboxylic acids in the Antarctic aerosols, in comparison with their molecular distributions in the Arctic and in the northern hemisphere.

\section{Samples and Methods}

Submicron aerosols $(<0.7 \mu \mathrm{m})$ were collected at Syowa Station $\left(69^{\circ} 00^{\prime}, 39^{\circ} 35^{\prime}\right.$; altitude, $21 \mathrm{~m}$ ) in February to December 1991 using a high-volume impactor sampler (Kimoto model CPS-105) on a precombusted $\left(450^{\circ} \mathrm{C}\right.$, 3 hours) quartz fiber filter (Pallflex, $20 \mathrm{~cm} \times 25 \mathrm{~cm}$ ). Larger aerosols $(>0.7 \mu \mathrm{m})$ were collected only for $\mathrm{X}$ ray microanalyses and were not available in this study. Air sample volumes were $2000-2600 \mathrm{~m}^{3}$. Filters were stored in a clean glass jar with a Teflon-lined screw cap before and after air sampling. Aerosol filters were stored at $-20^{\circ} \mathrm{C}$ prior to analysis.

The filter samples and field blank were analyzed by the method of Kawamura and Ikushima [1993] and
Sempéré and Kawamura [1994]. Briefly, an aliquot of the filters was extracted for low molecular weight dicarboxylic acids and other water soluble organic compounds with pure water prepared by distillation after $\mathrm{KMnO}_{4}$ oxidation of Mili $\mathrm{Q}$ water. The water extracts were concentrated using a rotary evaporator under vacuum and dried by a nitrogen blow down system. The diacids and related compounds were reacted with a $14 \%$ $\mathrm{BF}_{3} / \mathrm{n}$-butanol at $100^{\circ} \mathrm{C}$ for $60 \mathrm{~min}$ to derive dibutyl esters for carboxyl group and dibutoxy acetal for aldehyde group. After the reaction, the derivatives were extracted with n-hexane, washed with pure water, and dissolved in $50 \mu \mathrm{L} \mathrm{n}$-hexane.

Dicarboxylic acid dibutyl esters and related compounds were determined using a Hewlett Packard (HP 5890) gas chromatograph (GC) equipped with a split/ splitless injector, a HP-5 fused silica capillary column (0.32 mm ID $\times 25 \mathrm{~m}$ long, $0.52-\mu \mathrm{m}$ film thickness) and an FID (flame ionization detector). Identification of the compounds was performed by comparing $\mathrm{GC}$ retention times of authentic $\mathrm{C}_{2}-\mathrm{C}_{11}$ diacid dibutyl ester standards. The identifications were confirmed by examination of mass spectra, which were obtained with a Finnigan MAT ITS40 GC/MS system. Mass spectral information of the compounds reported here are given elsewhere [Kawamura and Ikushima, 1993; Kawamura, 1993]. Recoveries of authentic diacids spiked to a quartz fiber filter were $71 \%$ for oxalic acid and better than $90 \%$ for malonic, succinic, and adipic acids. Part of the filter samples (approximately $20 \mathrm{~cm}^{2}$ ) were cut off and subjected to an elemental analyzer (Yanagimoto model MT-3) for the measurement of total carbon and nitrogen contents [Sempéré and Kawamura, 1994].

\section{Results and Discussion}

Table 1 presents total carbon (TC) and total nitrogen (TN) contents for the Antarctic aerosol samples, as well as sampling dates, ambient temperature, and solar radiation. Concentration ranges of TC and TN were 440-1020 $\mathrm{ng} \mathrm{m}^{-3}$ and $11-170 \mathrm{ng} \mathrm{m}^{-3}$, respectively. The Antarctic aerosol TC contents (average $750 \mathrm{ng} \mathrm{m}^{-3}$ ) are 1 order of magnitude lower than those (average 22,000 $\mathbf{n g} \mathbf{~ m}^{-3}$ ) of urban Tokyo aerosols, whereas the TN contents (average $56 \mathrm{ng} \mathrm{m}^{-3}$ ) were 2 orders of magnitude lower than those (average $5,300 \mathrm{ng} \mathrm{m}^{-3}$ ) of the Tokyo aerosols [Kawamura et al., 1995b]. However, TC contents in the Antarctic aerosols are similar to or even higher than those of the Arctic aerosols from Alert (February to June 1991: $88-639 \mathrm{ng} \mathrm{m}{ }^{-3}$, average 359 $\mathrm{ng} \mathrm{m}^{-3}$ (K. Kawamura et al., manuscript in preparation, 1996). The Antarctic submicron aerosols showed very high $\mathrm{C} / \mathrm{N}$ weight ratios of $36-89$ for the autumn to winter samples (S2 and S3) and a high $\mathrm{C} / \mathrm{N}$ ratio of 15 for the winter to spring sample (S4). However, the summer aerosols showed a $\mathrm{C} / \mathrm{N}$ ratio of 6.0 ( $\mathrm{S} 5$, see Table 1$)$, which is similar to Redfield-Richards ratio $(\mathrm{C} / \mathrm{N}$ weight ratio of 5.7 [Libes, 1992]). This suggests that the summer aerosols mainly originate from marine organisms. This is consistent with the predominance of $\mathrm{C}_{12}, \mathrm{C}_{14}$, $\mathrm{C}_{16}$, and $\mathrm{C}_{18}$ monocarboxylic acids in the distributions 
Table 1. Total Carbon and Total Nitrogen Contents in the Antarctic Aerosols from Syowa Station with Sampling Dates and Solar Radiation

\begin{tabular}{|c|c|c|c|c|}
\hline & $\mathrm{S} 2$ & S3 & S4 & S5 \\
\hline Sampling dates & $\begin{array}{l}\text { March } 19 \text { to April 29, } \\
1991\end{array}$ & $\begin{array}{l}\text { May } 13 \text { to June 9, } \\
1991\end{array}$ & $\begin{array}{l}\text { Aug. } 29 \text { to Oct. } 29 \text {, } \\
1991\end{array}$ & $\begin{array}{l}\text { Nov. } 28 \text { to Dec. } 31 \text {, } \\
1991\end{array}$ \\
\hline Ambient temperature, deg & -10.7 & -17.1 & -17.8 & -0.8 \\
\hline Solar radiation, $\mathrm{MJ} \mathrm{m}^{-2}$ & 6.5 & 0.6 & 28.9 & 58.0 \\
\hline Air volume, $\mathrm{m}^{3}$ & 2457 & 2017 & 2643 & 2330 \\
\hline Total Carbon, $\mathrm{ng} \mathrm{m}^{-3}$ & $\mathbf{5 7 0}$ & 980 & 440 & 1020 \\
\hline Total Nitrogen, $n g \mathrm{~m}^{-3}$ & 16 & 11 & 29 & 170 \\
\hline $\mathrm{C} / \mathrm{N}$ ratio & 35.6 & 89.1 & 15.2 & 6.0 \\
\hline
\end{tabular}

of lipids in the Antarctic summer aerosols [Nishikiori et al., 1996]. The $\mathrm{C} / \mathrm{N}$ ratios in the Antarctic aerosols are much greater than those of the urban atmosphere (approximately 2 [Kawamura et al., 1995b]), where a gas to particle conversion of anthropogenic $\mathrm{NO}_{x}$ is significant.

A homologous series of $\alpha, \omega$-dicarboxylic acids $\left(\mathrm{C}_{2}\right.$ $\mathrm{C}_{11}$ ), and aromatic acid (phthalic acid) were detected in the Antarctic aerosols, as well as $\omega$-oxocarboxylic acids $\left(\mathrm{C}_{2}-\mathrm{C}_{6}, \mathrm{C}_{8}-\mathrm{C}_{9}\right), \alpha$-ketoacid (pyruvic acid), and $\alpha$-dicarbonyls $\left(\mathrm{C}_{2}-\mathrm{C}_{3}\right)$, as shown in Figure 1. Among these water soluble compounds, dicarboxylic acids are the most abundant compound class $\left(5.9-88.6 \mathrm{ng} \mathrm{m}^{-3}\right.$, average $29 \mathrm{ng} \mathrm{m}^{-3}$ ), followed by $\omega$-oxocarboxylic acids (0.70-3.05 $\mathrm{ng} \mathrm{m}^{-3}$, average $\left.1.4 \mathrm{ng} \mathrm{m}^{-3}\right)$ and $\alpha$ dicarbonyls $\left(0.15-0.97 \mathrm{ng} \mathrm{m}^{-3}\right.$, average $\left.0.40 \mathrm{ng} \mathrm{m}^{-3}\right)$ (see Table 2). Succinic $\left(\mathrm{C}_{4}\right)$ or oxalic $\left(\mathrm{C}_{2}\right)$ acid was found as the most abundant diacid species. The diacids with more carbon numbers are generally less abundant. The concentrations of the total diacids in the Antarctic aerosols are much lower than those of diacids in the urban aerosols from midlatitudes (90-1400 $\mathrm{ng} \mathrm{m}^{-3}$, average $480 \mathrm{ng} \mathrm{m}^{-3}$ [Kawamura and Ikushima, 1993]) and marine aerosols from western North Pacific (20-1040 ng $\mathrm{m}^{-3}$, average $245 \mathrm{ng} \mathrm{m}^{-3}$, [Kawamura and Usukura, 1993]) . However, their concentration levels are com-

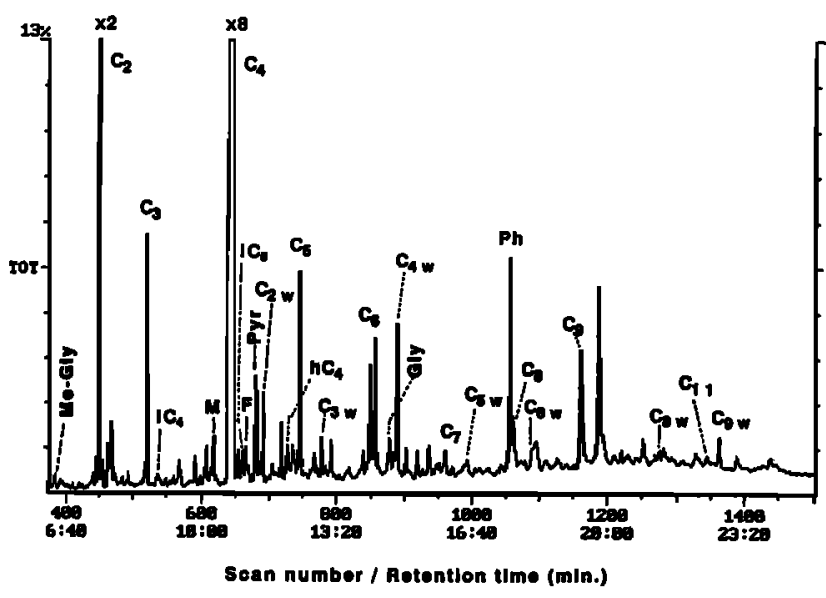

Figure 1. A reconstructed total ion chromatogram (TOT) of dicarboxylic acid dibutyl esters and related compounds isolated from the Antarctic submicron aerosols (S-5). parable to or even higher than those from the central North Pacific (16-53 $\mathrm{ng} \mathrm{m}^{-3}$, average $35 \mathrm{ng} \mathrm{m}^{-3}$ [Kawamura and Usukura, 1993]).

Highest concentrations of the total diacids $(88.6 \mathrm{ng}$ $\mathrm{m}^{-3}$ ) were obtained in the summer aerosol sample (Table 2). In the summer sample, succinic acids (61.5 $\mathrm{ng}$ $\mathrm{m}^{-3}$ ) accounted for $69 \%$ of the total diacids. Although succinic acid $\left(\mathrm{C}_{4}\right)$ has often been detected at a high concentration level in the continental aerosols, the predominance of this acid has not been obtained in the marine and continental atmosphere from the northern hemisphere [Kawamura and Usukura, 1993; Kawamura and Ikushima, 1993]. Previous studies showed that oxalic acid $\left(\mathrm{C}_{2}\right)$ is always the most abundant diacid and that relative abundances of succinic acid $\left(\mathrm{C}_{4}\right)$ are less than $8 \%$ of the total diacids [Kawamura and Ikushima, 1993; Kawamura and Usukura, 1993; Kawamura et al., 1995a]. In contrast, the ice core samples from south Greenland showed a predominance of succinic acid [Kawamura and Yasui, 1991]. This suggests that $\mathrm{C}_{4}$ diacid is produced from a specific source and reaction mechanism in the remote atmosphere free from pollution sources.

Although diacids with more carbon numbers are generally less abundant, azelaic acid $\left(\mathrm{C}_{9}\right)$ was detected as a relatively abundant species, and its highest concentration was observed in the summer sample. The $\mathrm{C}_{9}$ diacid has been considered as a specific product in the photochemical oxidation of unsaturated fatty acids, which contain a double bond, predominantly at C-9 position [Yokouchi and Ambe, 1986; Kawamura and Gagosıan, 1987]. Branched chain dicarboxylic acids such as methylmalonic (iso $\mathrm{C}_{4}$ ) and methylsuccinic (iso $\mathrm{C}_{5}$ ) acids were also detected; however, their abundances are far less than those of the corresponding straight chain diacids. Unsaturated diacids including maleic acid were detected in the aerosol samples as minor diacid species. In all the samples, the cis configuration is more abundant than the trans configuration. Aromatic (phthalic) acid was detected as a relatively abundant diacid. These diacids also showed the highest concentrations in the summer aerosols, suggesting that they are photochemically produced from aromatic structures which may be produced in the ocean and emitted to the atmosphere.

The diacid carbon concentrations in the total carbon (TC) contents ranged from $0.46 \%$ to $3.5 \%$ (average $1.35 \%)$. The highest value was obtained in the sum- 
Table 2. Concentrations of Dicarboxylic Acids, Oxocarboxylic Acids, and $\alpha$ Dicarbonyls in the Antarctic Aerosols Collected From Syowa Station in 1991

\begin{tabular}{|c|c|c|c|c|c|}
\hline Compounds & Abbreviation & S2 & $\mathrm{S} 3$ & $\$ 4$ & S5 \\
\hline \multicolumn{6}{|l|}{ Dicarboxylic acids } \\
\hline Oxalic (Ethanedioic) & $\mathrm{C}_{2}$ & 1.59 & 3.12 & 3.26 & 10.29 \\
\hline Malonic (Propanedioic) & $\mathrm{C}_{3}$ & 0.13 & 0.38 & 0.52 & 2.69 \\
\hline Methylmalonic & $\mathrm{iC}_{4}$ & 0.05 & 0.05 & 0.05 & 0.24 \\
\hline Maleic (cis Butenedioic) & $\mathrm{M}$ & 0.19 & 0.38 & 0.18 & 0.96 \\
\hline Succinic (Butenedioic) & $\mathrm{C}_{4}$ & 0.63 & 5.77 & 1.18 & 61.53 \\
\hline Methylsuccinic & $\mathrm{iC}_{5}$ & 0.10 & 0.13 & 0.11 & 0.18 \\
\hline Fumaric (trans Butenedioic) & $\mathbf{F}$ & 0.04 & BDL & 0.23 & 0.23 \\
\hline Methylmaleic & $\mathbf{m M}$ & BDL & BDL & 0.06 & $\mathrm{BDL}$ \\
\hline Malic (Hydroxybutanedioic) & $\mathrm{hC}_{4}$ & 0.15 & 0.03 & 0.00 & 0.70 \\
\hline Glutaric (Pentanedioic) & $\mathrm{C}_{5}$ & 0.31 & 0.58 & 0.34 & 2.26 \\
\hline Adipic (Hexanedioic) & $\mathrm{C}_{6}$ & 0.49 & 0.85 & 0.33 & 1.81 \\
\hline Pimelic (Heptanedioic) & $\mathrm{C}_{7}$ & 0.46 & 0.52 & 0.23 & 0.94 \\
\hline Suberic (Octanedioic) & $\mathrm{C}_{8}$ & 0.21 & 0.28 & 0.21 & 0.96 \\
\hline Phthalic & $\mathbf{P h}$ & 0.92 & 1.68 & 0.87 & 2.61 \\
\hline 4-Oxopimelic & $\mathrm{C}_{7,4-o x o}$ & BDL & 0.41 & 0.09 & 0.53 \\
\hline Azelaic (Nonanedioic) & $\mathrm{C}_{9}$ & 0.55 & 1.09 & 0.30 & 2.22 \\
\hline Sebacic (Decanedioic) & $\mathrm{C}_{10}$ & BDL & 0.06 & 0.08 & 0.17 \\
\hline Undecanedioic & $\mathrm{C}_{11}$ & 0.14 & 0.10 & 0.04 & 0.28 \\
\hline Subtotal & & 5.96 & 15.43 & 8.08 & 88.60 \\
\hline \multicolumn{6}{|l|}{$\omega$-Oxocarboxylic acids } \\
\hline Glyoxylic (Oxoethanoic) & $\mathrm{C}_{2 \omega}$ & 0.22 & 0.30 & 0.36 & 0.38 \\
\hline 3-Oxopropanoic & $\mathrm{C}_{3 \omega}$ & 0.07 & 0.06 & 0.05 & 1.03 \\
\hline 4-Oxobutanoic & $\mathrm{C}_{4 \omega}$ & 0.18 & 0.28 & 0.19 & 1.00 \\
\hline 5-Oxopentanoic & $\mathrm{C}_{5 \omega}$ & BDL & BDL & 0.02 & 0.09 \\
\hline 6-Oxohexanoic & $\mathrm{C}_{6 \omega}$ & 0.08 & 0.39 & 0.01 & 0.11 \\
\hline 7-Oxoheptanoic & $\mathrm{C}_{7 \omega}$ & BDL & BDL & BDL & BDL \\
\hline 8-Oxooctanoic & $\mathrm{C}_{8 \omega}$ & 0.05 & 0.12 & 0.02 & 0.18 \\
\hline 9-Oxononanoic & $\mathrm{C}_{9 \omega}$ & 0.18 & 0.08 & 0.05 & 1.16 \\
\hline Subtotal & & 0.78 & 1.23 & 0.70 & 3.05 \\
\hline \multicolumn{6}{|l|}{$\alpha$-Ketoacid } \\
\hline Pyruvic & Pyr & 0.32 & 0.22 & 0.14 & 0.78 \\
\hline \multicolumn{6}{|l|}{$\alpha$-Dicarbonyls } \\
\hline Glyoxal (Ethanedial) & Gly & 0.05 & 0.05 & 0.16 & 0.08 \\
\hline Methylgloxal & MeGly & 0.10 & 0.10 & 0.81 & 0.23 \\
\hline subtotal & & 0.15 & 0.15 & 0.97 & 0.31 \\
\hline total & & 7.21 & 17.03 & 9.89 & 92.74 \\
\hline
\end{tabular}

Values are in nanograms per cubic meter.

$\mathrm{BDL}$, below detection limit (approximately $0.01 \mathbf{n g ~ m}^{-3}$ ).

mer aerosol sample, suggesting an enrichment of the diacids in the Antarctic aerosols by photochemical reactions. The relative abundance of diacid-carbon in the aerosol TC is much higher than those of urban aerosols from Tokyo (0.06-1.1\%, average $0.46 \%$ [Kawamura and Ikushima, 1993]). The lower values in urban aerosols may be due to the abundant presence of elemental carbon. The diacid-C/TC ratios in the Antarctic aerosols are comparable to those of the Arctic aerosols collected from February to June at Alert (1.5-9.1\%, average 3.6\% (K. Kawamura et al., manuscript in preparation, 1996) and the remote marine atmosphere from central and North Pacific (1.2-16\%, average 9.1\% (Sakaguchi and Kawamura, submitted manuscript, 1996). These results suggest that in the remote atmosphere, organic aerosol composition is largely controlled by photochemical reactions.
Solar radiation and ambient temperature showed maxima during the S-5 (summer) sample collection (Table 1). Figure 2 plots concentrations of major diacid-carbon and $\omega$-oxoacid-carbon normalized by total aerosol carbon (TC) as a function of solar radiation. Oxalic $\left(\mathrm{C}_{2}\right)$ and malonic $\left(\mathrm{C}_{3}\right)$ acids showed a strong positive correlation with solar radiation ( $r>0.97)$, suggesting that they are in situ produced in the atmosphere by photochemical reactions of precursor organics. Longer chain diacids greater than or equal to $\mathrm{C}_{4}$ also showed positive correlation with solar radiation $(r=0.73-0.94)$, although confidence levels are relatively low. Abundant presence of succinic acid $\left(\mathrm{C}_{4}\right)$ in the Antarctic summer aerosols suggests that the $\mathrm{C}_{4}$ diacid is produced by the photochemical oxidation of marine organic precursors, whose sea-to-air emission should be enhanced due to a retreat of sea ice near the Antarctic coasts. Concentrations of 

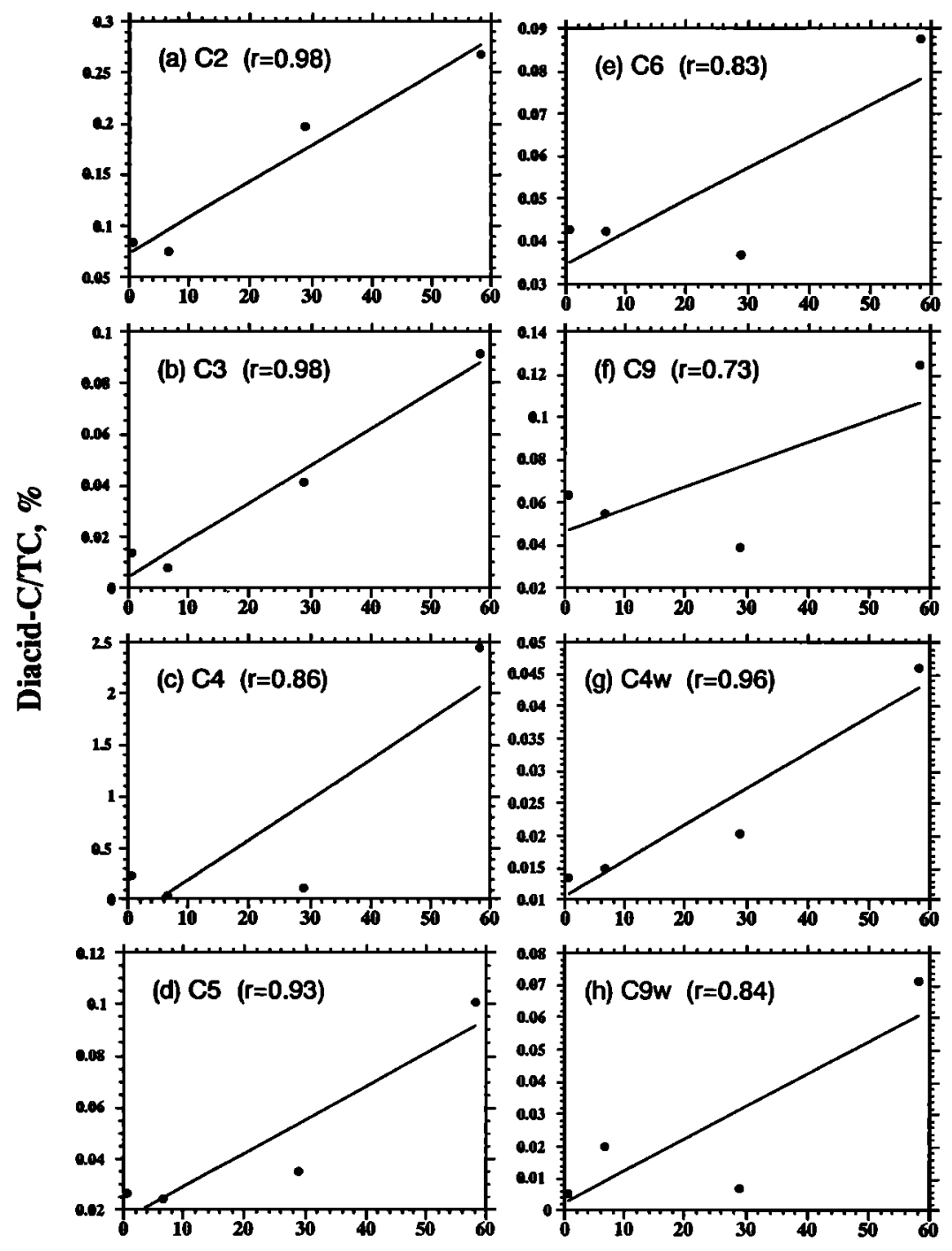

Solar radiation, $\mathbf{M J} \mathbf{~ m}^{-2}$

Figure 2. Relationships between concentrations of dicarboxylic acid-carbon and $\omega$-oxocarboxylic acid-carbon normalized by total aerosol carbon contents (TC) and solar radiation in the Antarctic atmosphere. For abbreviations, see Table 2.

$\omega$-oxocarboxylic acids $\left(\mathrm{C}_{4 \omega}\right.$ and $\left.\mathrm{C}_{9 \omega}\right)$ in TC also positively correlate with the solar radiation. The highest values of both $\mathrm{C}_{9}$ diacid and $\mathrm{C}_{9} \omega$-oxoacid in the summer sample (Figure 2, Table 2) suggest that they are produced by the oxidation of particulate unsaturated fatty acids containing a double bond predominantly at C-9 position [Kawamura and Gagosian, 1987].

As a precursor of succinic acid, we consider that midchain oxocarboxylic acids with keto group at C-4 position are likely candidates. Homologous series of midchain ketocarboxylic acids with keto group at different positions have been reported in the remote marine aerosols from North Pacific [Kawamura and Gagosian, 1988] and the equatorial and South Pacific (K. Kawamura and K. Tanaka, unpublished results, 1995). Interestingly, 4-oxooctanoic and 4-oxononanoic acids were also detected in the Antarctic aerosols as major ke- toacids [Nishikiori et al., 1996]. These midchain ketoacids have been considered to be produced by the atmospheric oxidation of semivolatile fatty acids which are the counterparts of $\alpha, \omega$ dicarboxylic acid (azelaic acid, $\mathrm{C}_{9}$ ), or $\omega$-oxononanoic acid, produced by photooxidation of unsaturated fatty acids [Kawamura and Gagosian, 1990]. Further oxidation of positional isomers of midchain ketoacids probably produce a homologous series of $\alpha, \omega$-dicarboxylic acids by heterogeneous reactions on aerosol surfaces (Figure 3 ). Enhanced concentrations of $\mathrm{C}_{4}$ and other diacids $\left(\mathrm{C}_{5}, \mathrm{C}_{6}, \mathrm{C}_{7}\right.$, and $\mathrm{C}_{8}$ ) in the summer aerosols (Table 2) seem to support the reaction pathways described in Figure 3.

Also detected in the Antarctic atmosphere was 4oxopimelic acid, $\mathrm{C}_{7}$ dicarboxylic acid with an additional keto group at C-4 position. The keto diacid showed the highest concentration in the summer aerosols. This 


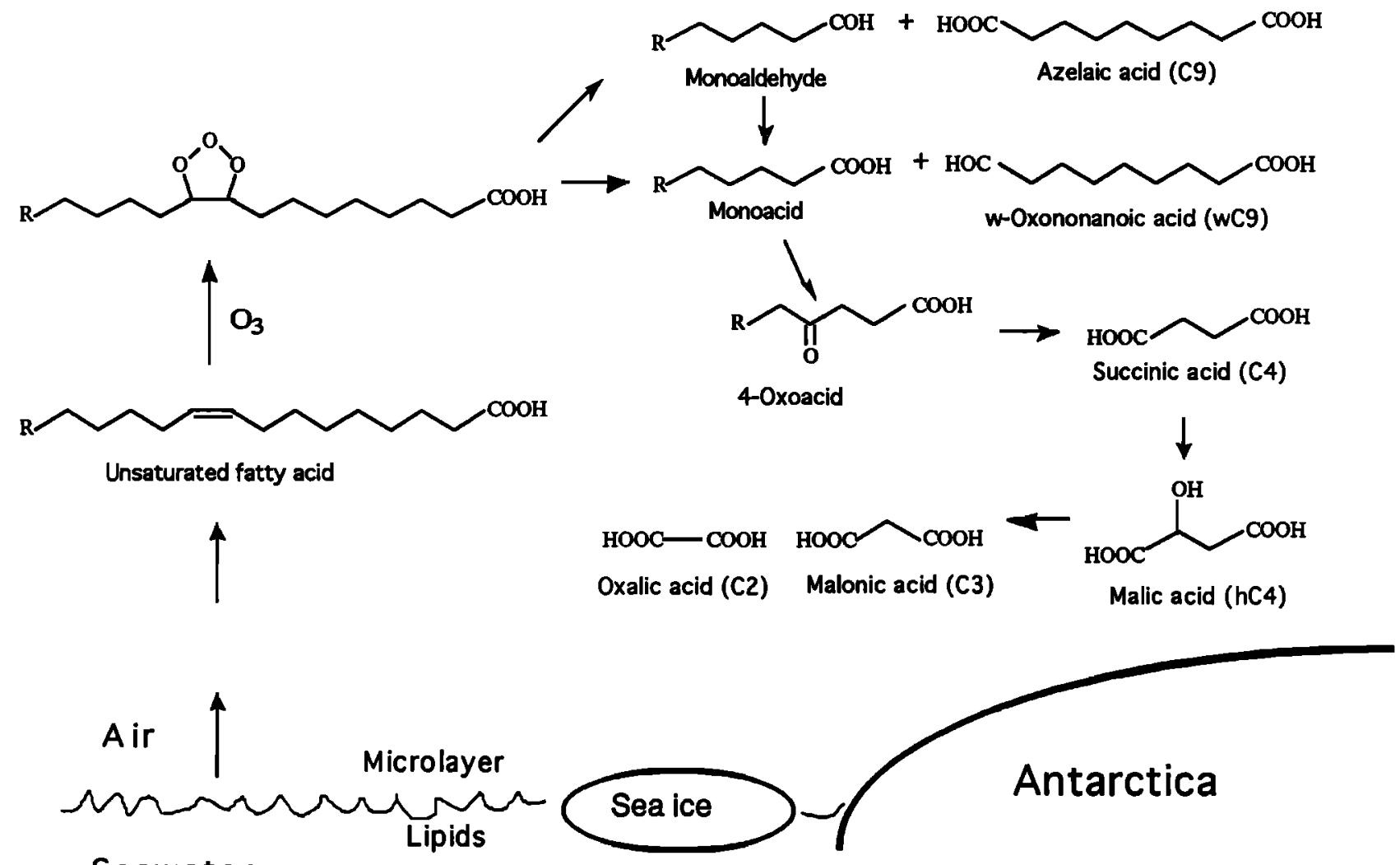

\section{Seawater}

Figure 3. A proposed reaction scheme for the production of succinic acid $\left(\mathrm{C}_{4}\right)$ and other low molecular weight dicarboxylic acids from unsaturated fatty acids and their photooxidation intermediates in the atmosphere of the Southern Ocean and Antarctica.

compound has been detected in the remote marine atmosphere [Sakaguchi and Kawamura, 1994] and is considered as a photooxidation product of $\mathrm{C}_{7}$ diacid. Also, 4-oxopimelic acid could be further oxidized in the atmosphere to result in succinic acid $\left(\mathrm{C}_{4}\right)$.

Highest concentrations of $\omega$-oxocarboxylic acids and pyruvic acid were also obtained in the summer aerosol sample (Table 2). $\omega$-Oxononanoic acid has been proposed as a photochemical oxidation product of unsaturated fatty acids [Kawamura and Gagosian, 1987]. In the Antarctic aerosols, 9-oxononanoic acid was detected as the most abundant $\omega$-oxoacids, and its concentration was found to be highest in the summer aerosols (S-5), again supporting the reaction scheme on the atmospheric oxidation of unsaturated fatty acids (Figure $3)$.

These considerations lead to the conclusion that organic aerosols over the coast of Antarctica are significantly influenced by the sea-to-air emission of marine organic matter and subsequent photochemical transformation. The sea-to-air emissions should be enhanced during summer season due to a retreat of sea ice, as stated above. Unsaturated fatty acids are major lipids compounds in the marine micro algae and are enriched in the microlayers of sea surfaces [Marty et al., 1979]. Enhanced emission of seawater microlayer lipids as aerosol particles to the marine atmosphere, coupled with intensified solar radiation in the Austral summer, probably cause a significant photochemical production of dicarboxylic acids and modifies the chemical constituents of the marine aerosols near Antarctica. Alternatively, it is likely that the diacids and related compounds which are produced in the Southern Ocean atmosphere are transported long distances over the Antarctic coast with a seasonality of summer maximum. This observation at Syowa Station suggests that the marine aerosols containing photooxidation products may be transported farther to inland Antarctica and deposited over the ice sheet by dry and/or wet precipitation processes.

As stated above, the molecular distributions of dicarboxylic acids in the Antarctic submicron aerosols are different from those of the Arctic aerosols $\left(82^{\circ} \mathrm{N}\right.$ [Kawamura et al., 1995a]). This suggests a difference in the source organic matter between the Arctic and Antarctic aerosols. In the Arctic atmosphere, a major portion of oxalic acid is produced by the photochemical oxidation of anthropogenic aromatic hydrocarbons such as benzene and toluene and their reaction intermediates, which are transported long-range from midlatitudes toward the Arctic during winter to spring [Kawamura et al., 1995a]. In contrast, the diacid distributions of the Antarctic aerosols indicate that anthropogenic organics are not the major precursors, rather, biogenic organic 
precursors such as unsaturated fatty acids significantly contribute to the Antarctic aerosol constituents. However, the aerosols collected in autumn to spring sometimes indicate a predominance of oxalic acid. This may suggest that except for Austral summer, atmospheric transport of aerosols from midlatitudes to the south occurs, and organic aerosols are subjected to photochemical transformation to produce oxalic and malonic acids during a long-range atmospheric transport to the Antarctica.

\section{Conclusions and Summary}

GC and GC/MS study of the Antarctic aerosols showed the presence of a homologous series of dicarboxylic acids $\left(\mathrm{C}_{2}-\mathrm{C}_{11}\right)$, $\omega$-oxocarboxylic acids $\left(\mathrm{C}_{2}-\mathrm{C}_{9}\right)$, and $\alpha$-dicarbonyls $\left(\mathrm{C}_{2}-\mathrm{C}_{3}\right)$. The maximum concentrations of diacids and $\omega$-oxoacids were observed in the Austral summer sample. The molecular distribution of the summer aerosols is characterized by a predominance of succinic acid $\left(\mathrm{C}_{4}\right)$, which differs from the distributions in the Arctic and other northern hemisphere aerosols, in which oxalic acid $\left(\mathrm{C}_{2}\right)$ is always dominant. The distributions of dicarboxylic acids and $\omega$-oxocarboxylic acids and their seasonal trend suggest that the Antarctic aerosols are not contributed from pollution sources, rather, their organic constituents are significantly controlled by sea-to-air emission of marinederived organic matter and their subsequent atmospheric photochemical oxidation. These water soluble organic compounds should be present in the ice sheet and could be used as potential tracers to reconstruct past changes in the atmospheric environments.

\section{Appendix}

CA registry numbers are as follows: oxalic acid, 14462-7; malonic acid, 141-82-2; methylmalonic acid, 51605-2; maleic acid, 110-16-7; succinic acid, 110-15-6; methylsuccinic acid, 498-21-5; fumaric acid, 110-17-8; methylmaleic acid, 498-23-7; malic acid, 6915-15-7; glutaric acid, 110-94-1; adipic acid, 124-04-9; pimelic acid, 111-16-0; suberic acid, 505-48-6; phthalic acid, 88-99-3; azelaic acid, 123-99-9; sebacic acid, 111-20-6; undecanedioic acid, 1852-04-6; glyoxylic acid, 298-12-4; pyruvic acid, 127-17-3; and methylglyoxal, 78-98-8.

Acknowledgments. We thank Dr. T. Kikuchi of Science University of Tokyo for the courtesy of the use of high volume air sampler. This work was supported in part by the Ministry of Education, Science and Culture through grantin-aid 06453009 .

\section{References}

Barrie, L. A., Arctic air pollution: An overview of current knowledge, Atmos. Environ., 20, 643-663, 1986.

Barrie, L. A., and M. J. Barrie, Chemical components of lower tropospheric aerosols in the high Arctic: Six years of observations, J. Atmos. Chem., 11, 211-226, 1990.
Delmas, R., Environmental information from ice cores, Rev. Geophys., 30, 1-21, 1992.

Grosjean, D., K. Van Cauwenberghe, J. P. Schmid, P. E. Kelley, and J. N. Pitts Jr., Identification of $\mathrm{C}_{3}-\mathrm{C}_{10}$ aliphatic dicarboxylic acids in airborne particulate matter, Environ. Sci. Technol., 12, 313-317, 1978.

Hatakeyama, S., T. Tanonaka, J. Weng, H. Bandow, H. Takagi, and H. Akimoto, Ozone-cyclohexene reaction in air: Quantitative analysis of particulate products and the reaction mechanism, Environ. Sci. Technol., 19, 935-942, 1985.

Hatakeyama, S., M. Ohno, J. Weng, H. Takagi, and H. Akimoto, Mechanism for the formation of gaseous and particulate products from ozone cycloalkene reactions in air, Environ. Sci. Technol., 21, 52-57, 1987.

Itoh, T., Antarctic submicron aerosols and long-range transport of pollutants, Ambit, 18, 34-41, 1989.

Kawamura, K., Identification of $\mathrm{C}_{2}-\mathrm{C}_{10} \omega$-oxocarboxylic acids, pyruvic acid, and $\mathrm{C}_{2}-\mathrm{C}_{3} \alpha$-dicarbonyls in wet precipitation and aerosol samples by capillary GC and GC/MS, Anal. Chem., 65, 3505-3511, 1993.

Kawamura, K., and R. B. Gagosian, Implication of $\omega$ oxocarboxylic acids in the remote marine atmosphere for photo-oxidation of unsaturated fatty acids, Nature, 325, 330-332, 1987.

Kawamura, K., and R. B. Gagosian, Identification of aliphatic keto carboxylic acids in marine aerosols using capillary gas chromatography-mass spectrometry, J. Chromatogr., 438, 299-307, 1988.

Kawamura, K., and R. B. Gagosian, Mid-chain ketocarboxylic acids in the remote marine atmosphere: Distribution patterns and possible formation mechanisms, $J$. Atmos. Chem., 11, 107-122, 1990.

Kawamura, K., and K. Ikushima, Seasonal changes in the distribution of dicarboxylic acids in the urban atmosphere, Environ. Sci. Technol., 27, 2227-2235, 1993.

Kawamura, K., and I. R. Kaplan, Motor exhaust emissions as a primary source for dicarboxylic acids in Los Angeles ambient air, Environ. Sci. Technol., 21, 105-110, 1987.

Kawamura, K., and K. Usukura, Distributions of low molecular weight dicarboxylic acids in the North Pacific aerosol samples, J. Oceanogr., 49, 271-283, 1993.

Kawamura, K., and O. Yasui, Organic acids and aldehydes in the ice samples from Site-J, Greenland, Bull. Glacier Res., 9, 59-63, 1991.

Kawamura, K., H. Kasukabe, O. Yasui, and L. A. Barrie, Production of dicarboxylic acids in the arctic atmosphere at polar sunrise, Geophys. Res. Lett., 22, 1253-1256, $1995 \mathrm{a}$.

Kawamura, K., M. Kosaka, and R. Sempéré, Distributions and seasonal changes of hydrocarbons in urban aerosols and rainwaters (in Japanese with an English abstract), Chikyu Kagaku (Geochem.), 29, 1-15, 1995b.

Li, S. M., and J. W. Winchester, Water soluble organic constituents in arctic aerosols and snow pack, Geophys. Res. Lett., 20, 45-48, 1993.

Libes, S. M., An Introduction to Marine Biogeochemistry, 734pp., John Wiley, New York, 1992.

Marty, J. C., A. Saliot, P. Buat-Menard, R. Chesselet, and K. A. Hunter, Relationship between the lipid composition of marine aerosols, the sea surface microlayers, and subsurface water, J. Geophys. Res., 84, 5707-5716, 1979.

Nishikiori, M., K. Kawamura, M. Hayashi, and Y. Fujii, Mono- and di-carboxylic acids and mid-chain oxocarboxylic acids in the Antarctic aerosols (in Japanese with an English abstract), Chikyu Kagaku (Geochem.), 30, 27 $34,1996$.

Norton, R. B., J. M. Roberts, and B. J. Huebert, Tropospheric oxalate., Geophys, Res. Lett., 10, 517-520, 1983. 
Sakaguchi, F., and K. Kawamura, Identification of 4-oxoheptanedioic acid in the marine atmosphere by a capillary gas chromatography-mass spectrometry, J. Chromatogr., 687, 315-321, 1994.

Satsumabayashi, H., H. Kurita, Y. Yokouchi, and H. Ueda, Photochemical formation of particulate dicarboxylic acids under long-range transport in central Japan, Atmos. Environ., 24A, 1443-1450, 1990.

Sempéré, R., and K. Kawamura, Comparative distributions of dicarboxylic acids and related polar compounds in snow, rain and aerosols from urban atmosphere, Atmos. Environ., 28, 449-459, 1994.

Yokouchi, Y., and Y. Ambe, Characterization of polar organics in airborne particulate matter, Atmos. Environ., 20, 1727-1734, 1986.
Y. Fujii, National Institute of Polar Research, 1-9-10 Kaga, Itabashi, Tokyo 173, Japan.

M. Hayashi, Solar Terrestrial Environment Laboratory, Nagoya University, Chikusa-ku, Nagoya 464-01, Japan.

K. Kawamura and Y. Imai, Institute of Low Temperature Science, Hokkaido University, N19 W8, Kita-ku, Sapporo 060, Japan (e-mail: kawamura@orange.lowtem.hokudai.ac.jp).

R. Sempéré, CNRS, Campus de Luminy, Marseille Cedex 9, France.

(Received September 28, 1995; revised March 8, 1996; accepted April 10, 1996.) 